\title{
Aksebilitas Pada Madrasah Ibtidaiyah Swasta di Kota Banjarmasin
}

\author{
Syarifah Salmah', Rahmad ${ }^{2}$ \\ 1Universitas Islam Negeri Antasari Banjarmasin, 2Institut Agama Islam Negeri Palangka Raya \\ ${ }^{1}$ syarifahsalmah@uin-antasari.ac.id, 2rahmad@iain-palangkaraya.ac.id
}

DOI. 10.18860/mad.v12i2.8712

Abstract. Indonesia is one of the countries that respects the human rights of its citizens. Based on the fundamental constitutional mandate that education is the right of every citizen without exception, one of the indicators is that educational institutions must open opportunities for every citizen. This study aims to evaluate the existing educational facilities in the city of Banjarmasin, precisely some private Islamic Elementary School (MIS). The method in this research is descriptive qualitative. This method aims to describe the situation as a whole and thoroughly related to the selected object. The results of research related to accessibility for people with disabilities still cannot be seen in some of MIS choosen as the object of this study. The results of this study get the fact that all research objects are not friendly to people with dissabilities, such as conventional school steps. Even though the rule of laws is complete, but in fact, the implementation of these laws still encountered some problems until now. Accessibility for disability is one indicator as a child-friendly school, so, hopefully this research will be a piece of initial information for stakeholders in the Ministry of Religion in improving the quality of essential Islamic education services.

Keywords. Accessibility; Private Islamic Elementary School; Disability

\begin{abstract}
Abstrak. Indonesia merupakan salah satu dari negara-negara yang menghargai HAM warga negaranya. Berdasarkan amanat konstitusi dasar bahwa pendidikan adalah hak warga negara, salah satu dari indikatornya adalah lembaga pendidikan harus membuka kesempatan kepada setiap warga negara. Penelitian ini untuk mengevaluasi fasilitas pendidikan yang ada di kota Banjarmasin, khususnya adalah beberapa Madrasah Ibtidaiyah Swasta (MIS). Metode dalam penelitian adalah deskriptif kualitatif, metode ini digunakan untuk menggambarkan keadaan secara utuh dan menyeluruh terkait objek yang dipilih. Hasil dari penelitian terkait aksesibilitas bagi penyandang disabilitas masih belum dapat dilihat pada beberapa MIS yang dipilih sebagai objek penelitian ini. Hasil penelitian ini mendapat fakta bahwa seluruh objek penelitian masih kurang atau tidak ramah disabilitas, seperti tangga-tangga sekolah yang masih konvensional. Padahal dasar hukum yang mengatur hal tersebut telah sangat lengkap, namun dalam implemetasinya masih tidak dapat dilaksnakan secara maksimal. Aksesibilitas untuk disabilitas adalah salah satu indikator sebagai sekolah ramah anak, untuk itulah diharapkan penelitian ini menjadi sebuah informasi awal bagi stake holder di lingkungan Kementrian Agama dalam meningkatkan kualitas layanan pendidikan dasar Islam.
\end{abstract}

Kata kunci. Aksesibilitas; Madrasah Ibtidaiyah Swasta; Disabilitas.

Received : 29-04-2020

Approved : :05-06-2020

Revised : 29-05-2020

Published : 24-06-2020

Copyright (C) Madrasah Jurnal Pendidikan dan Pembelajaran Dasar. All Right Reserved.

This is an open access article under the CC BY-NC-ND license

(http:/ / creativecommons.org/licenses/by-nc-nd/4.0/).

Correspondence Address: syarifahsalmah@uin-antasari.ac.id

Vol. 12 No. 2 Juni 2020

Madrasah homepage: http://ejournal.uin-malang.ac.id/index.php/madrasah/index 


\section{MADRASAH}

Jurnal Pendidikan dan Pembelajaran Dasar

p ISSN: 1979-5599 | e ISSN: 2502-194X

Pag e | 75

\section{A. PENDAHULUAN.}

The educational reform that followed included services and educational programs provided by the Ministry of Education and the Ministry of Social Development which adopt the principle "education for all" and accept the categories of students with disabilities in their schools and centers and put each of these categories in suitable programs that meet their needs (Alsafran \& Amireh, 2019, p. 1). Education for All (EFA) sedang marak digaungkan di seluruh belahan bumi. Hakekat dari "Education for All" atau pendidikan untuk semua pada intinya adalah mengupayakan agar setiap warga negara dapat memenuhi salah satu hak dasar yaitu layanan pendidikan. Indonesia dan seluruh bangsa di dunia berupaya untuk menjamin pendidikan untuk semua bagi setiap warganya termasuk para penyandang disabilitas.

Indonesia merupakan negara yang mempunyai kesadaran akan pentingnya hak asasi manusia (HAM) yang melekat pada setiap individu atau warga negara. Hak warga negara itu menyangkut berbagai hak atas dasar pemenuhan kebutuhan warga negara. Hak sebagai manusia untuk hidup, hak manusia mendapat kedudukan yang sama dalam bidang hukum, hak untuk mendapat penghidupan yang layak serta tentu saja hak untuk memperoleh pendidikan yang berkualitas. Pemenuhan hak dasar tersebut serta hak lainnya menjadi sebuah indikator keberhasilan Indonesia sebagai negara demokrasi yang telah menjalankan proses demokrasi dalam kehidupan sehari-hari warga negara Indonesia (WNI). Pemenuhan hak pendidikan tersebut juga merupakan sebuah bentuk kehadiran negara dalam upaya pemenuhan hak-hak dasar warga negara. Pendidikan merupakan hak warga negara tanpa terkecuali. Golongan masyarakat yang sering tidak mendapat akses pendidikan yang layak seperti disabilitas, orang miskin serta anak terlantar tentu menjadi sebuah pekerjaan bersama baik bagi pemerintah maupun masyarakat.

Dewasa ini Sekolah Ramah Anak (SRA) juga menjadi sebuah solusi dalam peningkatan kualitas pelayanan pendidikan. Sehingga sekolah memiliki budaya perilaku yang menjadi cerminan tingkah laku masyarakat sekolah. Budaya sekolah (Subur, Qosim, \& Nugroho, 2018, p. 354) adalah sekumpulan nilai yang menjiwai serta melandasai tingkah laku, kebiasaan dan keseharian serta symbol yang dipraktikkan oleh tenaga pendidik serta kependidikan dan siswa serta masyarakat disekitar sekolah tersebut. Terkait akses pendidikan bagi disabilitas. Indonesia telah meratifikasi konvensi PBB yang mengatur hak-hak penyandang disabilitas pada tanggal 30 Maret 2007 dan konvensi ini dikeluarkan bertepatan tanggal 13 Desember 2006. Tujuan negara dalam meratifikasi aturan ini adalah agar penyandang disabilitas mempunyai hak yang sama sebagaimana warga negara lainnya.

Pendidikan untuk individu berkebutuhan khusus menjadi sebuah wujud dari kesadaran terkait hak asasi manusia dan akan selalu berkembang sejalan dengan semakin kompleksnya kehidupan manusia itu sendiri. Hal ini dikarenakan individu berkebutuhan khusus atau kaum disabilitas adalah termasuk populasi masyarakat dalam urutan minoritas yang sangat rentan akan adanya diskriminasi pada setiap aspek kehidupan (Mahabbati, 2014). Konstitusi tertulis kita telah mengamanatkan adanya sebuah kewajiban bagi negara untuk mengusahakan suatu sistem pendidikan nasional yang meningkatkan keimanan serta ketakwaan serta akhlak mulia dalam rangka mencerdaskan kehidupan bangsa yang diatur dalam UUD 1945 pada pasal 31 ayat 3 . Pasal 28c (Undang-Undang Dasar 1945, 2002) pada salah satu bagiannya menyebutkan 
bahwa setiap orang berhak mendapat pendidikan. Pendidikan merupakan hak dasar yang juga berlaku untuk orang berkebutuhan khusus. Pada UU nomor 20 Tahun 2003 (Kementrian Pendidikan Nasional, 2003) pasal 11 (1) disebutkan bahwa terdapat kewajiban Pemerintah serta Pemerintah Daerah dalam memberi layanan untuk menyelenggarakan pendidikan bagi seluruh warga Negara dan tentunya tanpa diskriminasi dan terdapat pula penegasan peniadaan diskriminasi itu pula. Undang undang nomor 4 (Sekertaris Negara RI, 1997) pada pasal 6 ayat 1 berbunyi setiap kaum disabilitas berhak memperoleh pendidikan pada semua satuan, jalur, jenis, dan jenjang pendidikan.

Pendidikan inklusif menjadi sebuah hal yang mesti diperjuangkan bersama bagi anak-anak yang memiliki suatu keadaan tertentu. Tetapi pelayanan pendidikan menjadi justru menjadi susah dipenuhi akibat, apakah karena anak-anak masuk disebabkan berbagai kendala fisik, geografis, ekonomi dan sosial (Yusraini, 2013). Pengertian pendidikan inklusif (Kementrian Pendidikan Nasional, 2009) menurut Permendiknas nomor 70 yang dikeluarkan pada tahun 2009 menjelaskan terkait pendidikan inklusif yaitu secara garis besar adalah pemberian kesempatan bagi setiap siswa untuk belajar bersama dalam satu lingkungan pendidikan. Siswa disini adalah yang memiliki potensi memiliki bakat istimewa atau memiliki kekurangan. [ada Permendiknas nomor 70 tahun 2009 pasal 2 ayat 1 menyebutkan bahwa tujuan pendidikan inklusif adalah dapat kita telaah bahwa kesempatan akan selalu terbuka bagi setiap warga Negara, karena hak untuk mengenyam pendidikan merupakan salah satu hak dasar yang melekat kepada setiap warga Negara. Berdasarkan beberapa aturan hukum terkait perlindungan warga Negara dalam bidang pendidikan maka pemerintah provinsi Kalimantan Selatan mengeluarkan Perda nomor 17 Tahun 2013 tentang perlindungan dan pemenuhan hak penyandang disabilitas.

Kesetaraan menjadi poin penting terutama dalam penyelenggaraan pendidikan. Kota Banjarmasin sebagai ibukota Provinsi Kalimantan Selatan tentu menjadi sebuah daserah yang seharunya mampu menerapkan aturan tersebut yaitu perlindungan dan pemenuhan hak penyandang disabilitas terutama dalam bidang pendidikan. Pada perda tersebut pada pasal 9 butir 1 menyebutkan bahwa penyelenggara pendidikan pada semua jalur, jenis dan jenjang pendidikan selayaknya dan harus memberi kesempatan serta perlakuan yang setara dan wajib menerima peserta didik. Disebutkan bahwa sekolah wajib memberikan pelayanan yang disesuaikan dengan kondisi dan potensi peserta didik penyandang disabilitas dengan tetap memperhatikan kualitas. Berdasarkan perda tersebut kita dapat memaknai bahwa sekolah regular seharusnya dapat memberi kesempatan bagi peserta didik difabel untuk bersekolah di sekolah umum atau regular seperti madrasah ibtidaiyah tentu juga berlaku hal tersebut. Penerimaan peserta didik berkebutuhan khusus di sekolah regular pada pasal 14 ayat (2) dinyatakan pada butir a yang menyebutkan bahwa peningkatan aksesibilitas layanan pendidikan yang merata, bermutu dan proporsional juga akan di nikmati oleh segenap lapisan masyarakat. Namun tetap memperhatikan peningkatan kualitas sarana dan prasarana pendidikan yang tetap bermutu, kondusif serta efektif yang dinyatakan pada butir b.

Penelitian ini mencoba memberi gambaran terkait akses pendidikan pada lembaga pendidikan swasta atau madrasah ibtidaiyah swasta yang berada di bawah Kementrian Agama. Penelitian ini diharapkan dapat menjadi informasi awal bagi para stake holder yang tentu memerlukan masukan serta gambaran nyata terkait penentuan 


\section{MADRASAH}

Jurnal Pendidikan dan Pembelajaran Dasar

p ISSN: 1979-5599 | e ISSN: 2502-194X

Page $\mid 77$

kebijakan lanjutan. Posisi penelitian ini menjadi sangat penting pula karena dapat memberikan informasi awal terkait akses pendidikan yang setara tanpa terkecuali yang diselenggarakan oleh Kementrian Agama yang terkadang menurut penulis dapat dikatakan relatif lambat dalam mengimplementasikan peraturan yang telah ada, yang tentu dipengaruhi oleh berbagai permasalahan yang ada.

Sekolah/Madrasah merupakan suatu institusi atau lembaga yang dapat menghilangkan diskriminasi, oleh sebab itu juga harus menghilangkan pembedaan tersebut, tau dengan kata lain akses pendidikan yang terbuka luas bagi setiap warga Negara tanpa terkecuali. Sekolah sebagai instansi atau lembaga resmi harus dapat mewujudkan hal tersebut. Hal ini dikarenakan sekolah negeri adalah instansi pelaksana kebijakan pemerintah, dan harus mengupayakan agar instansi pendidikan dapat melaksanakan pendidikan inklusif tersebut.

Berdasarkan data tentang madrasah di Kalimantan Selatan yang diperoleh melalui situs http://emispendis.kemenag.go.id/dashboard/?content=data-statistik diperoleh data bahwa jumlah madrasah ibtidaiyah di Kalimantan Selatan yang berstatus negeri sebanyak 143 dan yang berstatus swasta sebanyak 390 Madrasah Ibtidayah Swasta. Berdasarkan jumlah kuantitas diperoleh fakta bahwa MIS memiliki jumlah yang lebih banyak sebesar hampir tiga kali lipat. Fakta ini menunjukkan bahwa MIS juga dapat menjadi sebuah pendukung kebijakan pemerintah terkait akses pendidikan yang merata dan didukung oleh fasilitas yang memadai tentunya. Apabila kita evaluasi bersama MIN tentu memiliki kesempatan dan akses informasi dan pendanaan yang lebih baik untuk menunjang keberhasilan program pemerintah, namun MIS tentu memiliki kekuatan dalam jumlah yang lebih besar dari MIN, namun terkait pendanaan dapat dikatakan MIS cenderung kalah dibandingkan MIN. tetapi hal ini menunjukkan posisi penting MIS dalam mensukseskan program pemerintah terkait akses pendidikan tentunya. Untuk itu penelitian ini mencoba untuk melihat sejauh mana program pendidikan inklusif berlangsung di instansi pendidikan dasar dalam hal ini adalah madrasah ibtidaiyah swasta di Kota Banjarmasin.

\section{B. HASIL DAN PEMBAHASAN}

\section{Hasil Penelitian}

\section{a. Aspek Yuridis Aksesesibilitas Bidang Pendidikan}

Pada tahun 1984 Indonesia meratifikasi Konvensi CEDEW melalui UU nomor 7 tahun 1984 tentang pengesahan Konvensi penghapusan segala bentuk diskriminasi terhadap perempuan meskipun sebelumnya telah ada Deklarasi HAM (Hasanah, 2016, p. 110). Hal ini contoh lain bahwa Indonesia telah menyatakan ketidak setujuan terhadap diskriminasi, salah satunya diskriminasi gender. Pada UU No 20 Tahun 2003 tentang Sisdiknas terdapat pernyataan kewajiban penyelenggaraan pendidikan khusus bagi penyandang disabilitas kemuidan pada PP No. 10 Tahun 2010 tertulis adanya keharusan bahwa instansi pendidikan tanpa terkecuali harus menerima peserta didik tanpa diskriminasi salah satunya adalah berdasarkan kondisi fisik dan mental, namun hingga kini, 90\% dari 1,5 juta anak dengan disabilitas justru tidak dapat menikmati pendidikan (Irwanto, Fransiska, \& Lusli, 2016).

Pada pasal 4 UU No. 8 Tahun 2016 disebutkan bahwa kriteria disabilitas meliputi 1) Disabilitas Fisik, 2) Disabilitas Intelektual, 3) Disabilitas Mental, 4) Disabilitas Sensorik. 
Pembagian inipun sepertinya banyak tidak diketahui oleh penyelenggara pendidikan. Dasar hukum terkait antara lain adalah dasar hukum tentang disabilitas pada UU No. 8 Tahun 2016 yang ternyata sejalan dengan UUD 1945, pada pada pasal 28C ayat 1 disebutkan bahwa manusia Indonesia berhak meningkatkan pengembangan diri melalui pemenuhan kebutuhan kebutuhan dasar serta berhak atas pendidikan dan dapat memperoleh manfaat serta akan meningkatkan kualitas hidupnya. Pasal 31 secara jelas disebutkan bahwa pendidikan merupakan hak yang memang harus diberikan.

Akses harus menjadi pertimbangan pertama dan utama dalam penyelenggaraan pendidikan inklusif ini. Akses menjadi indikator terkait kesempatan dalam mengenyam pendidikan bagi semua warga masyarakat, hal ini tentu berdasarkan UU disabilitas (Kementrian Hukum dan HAM, 2016) pada pasal 5 menyebutkan bahwa penyandang disabilitas memiliki hak-hak yang tercantum dan berbagai hak dasar ada didalamnya, salah satunya kita bisa cermati pada butir e yaitu masalah pendidikan dan pada butir $\mathrm{m}$ yaitu aksesibilitas yang dalam pengertian menurut UU No. 8 Tahun 2016 didefinisikan sebagai sebuah kemudahan yang disediakan untuk penyandang disabilitas sehingga akses atau kesempatan dapat diperoleh kaum difabel. Terkait bagaimana ketentuan bangunan atau sarana pendukung akses disabilitas tentu kita harus mengacu pada Permen PU No. 30 Tahun 2006 yang memang sudah ada walaupun UU tentang disabiltas disahkan. Jangka waktu yang cukup lama tersebut tentu seharusnya membuat sarana dan prasarana serta bangunan dan fasilitas penunjang akses bagi kaum diabilitas di instansi pendidikan atau sekolah/madrasah.

\section{b. Gambaran Fasilitas pada MIS di Kota Banjarmasin}

Terkait permasalahan sarana prasarana penunjang akses disabilitas di kota Banjarmasin berdasarkan penelitian saya sendiri pada tahun 2018 di semua MIN di kota Banjarmasin terdapat fakta bahwa tidak ada MIN di kota Banjarmasin yang memudahkan atau menyediakan akses yang cukup bagi peserta didik difabel. Kesulitan itu antara lain kamar kecil yang sulit diakses, akses menuju kelas belajar yang juga sulit diakses baik berupa selasar dan tangga yang sangat belum ada akses kemudahan bagi peserta didik difabel. Hal ini berakibat tidak ada satupun MIN di kota Banjarmasin yang memiliki peserta didik difabel (Salmah, 2018, p. 80). Penelitian ini merupakan kelanjutan penelitian terdahulu yang penulis lakukan terkait Aksesibilitas pendidikan bagi disabilitas pada Madrasah Ibtidaiyah Negeri di kota Banjarmasin. Namun pada penelitian ini penulis memfokuskan objek penelitian terhadap 7 (tujuh) madrasah ibtidaiyah swasta yang ada di Banjarmasin. Penelitian ini menekankan pada akses bagi siswa penyandang tuna daksa. Artinya kajian yang dilakukan merupakan analisis terkait sarana dan prasarana penunjang. Penambahan lokasi penelitian dapat di lihat melalui beberapa madrasah ibtidaiyah swasta di bawah ini:

\section{1) MIS Raudhatul Ulum.}

Sekolah ini memiliki bangunan cukup baik, sebagian besar bangunan sudah permanen, lantai sudah berupa keramik/ porselin, hanya beberapa ruangan seperti selasar antar kelas dan jalan menuju toilet yang masih menggunakan lantai kayu ulin, tangga-tangga juga masih terbuat dari kayu dan sangat curam hal ini juga tentunya masih menjadi kendala bagi siswa Tunadaksa. Berdasarkan hasil wawancara, ternyata sekolah ini juga belum ikut berdeklarasi SRA/ sekolah Ramah Anak, yang salah satu komitmennya adalah menyediakan fasilitas sekolah juga ramah untuk semua anak 


\section{MADRASAH}

Jurnal Pendidikan dan Pembelajaran Dasar

termasuk yang berkebutuhan khusus, hal ini karena kurangnya sosialisai Perda pun belum dilakukan oleh pemerintah daerah ke instansi pendidikan, serta kurangnya koordinasi dengan pihak-pihak terkait. Madrasah ini juga berada dibawah atau milik swasta. Kondisi fisik dapat dilihat seperti gambar berikut:

Gambar B.1 Kondisi Tangga

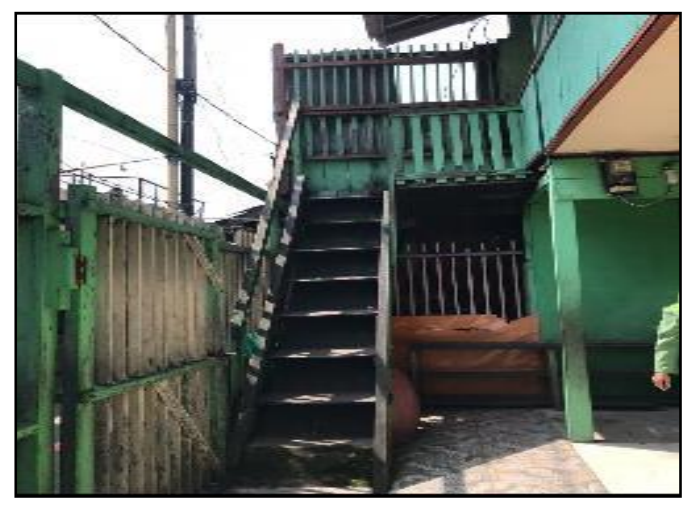

Gambar B. 2 Kondisi Lantai

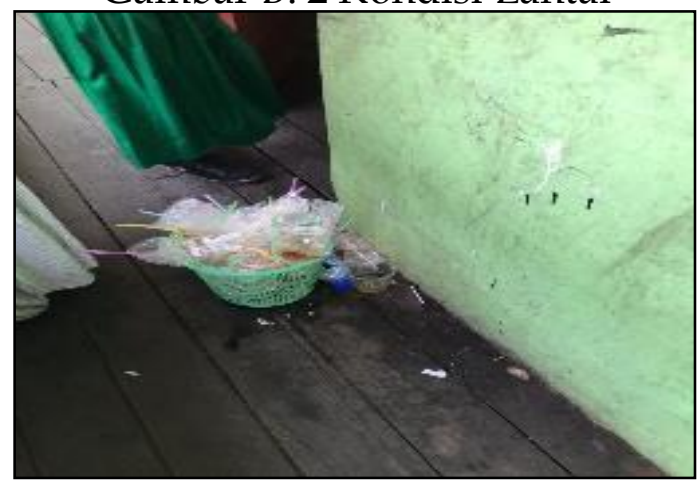

Gambar B.3 Kondisi Kelas



2) MI Khadijah

MI Khadijah beralamat di jalan Veteran gang Dwikora Kota Banjarmasin juga merupakan bangunan yang cukup berumur karena material madrasah sebagian besar adalah papan dan tingkat dua serta memiliki tangga tentunya untuk akses naik turun. Hal ini berdampak pada tuntutan akses naik turun yang seharusnya mudah diakses 
peserta didik dengan keterbatasan. Apalagi madrasah ini berada di bawah kepemilikan swasta. Lambaga pendidikan yang berada di bawah kepemilikan swasta tentu berbeda masalah pendanaan di bawah pemerintah. Tergantung kebijakan yayasan. Kembali dapat dikatakan karena kurangnya sosialisasi terkait Perda disabilitas yang mengakibatkan ketidaktahuan dari pihak sekolah.

Gambar B. 4 Kondisi Akses Menuju Ruang Kelas

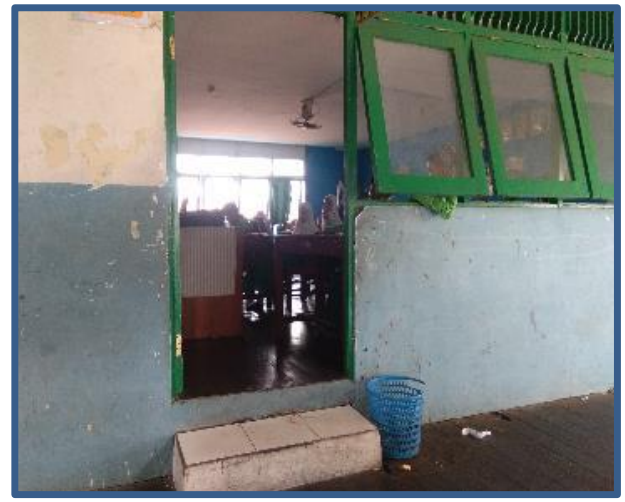

Berdasarkan hasil wawancara dan observasi pada sekolah ini penulis menemukan fakta bahwa dikarenakan sekolah ini baru saja melakukan deklarasai sekolah ramah anak, pihak sekolah sudah berupaya menciptakan lingkungan yang nyaman, seperti belajar diluar kelas dan karya wisata, sehingga anak didik senang belajarnya. Namun, secara fisik sekolah ini belum memenuhi standar untuk anak berkebutuhan khusus, karena bangunan fisik masih semi permanen dengan lantai, tangga dan fasilitas sekolah yang lain masih belum ramah bagi disabilitas.

\section{3) MIS Sulamut Taufiq}

Sekolah yang beralamat di jalan Manggis gang Taufiq RT. 27 No. 11 merupakan madrasah selanjutnya yang diobservasi. Pada sekolah ini bangunan masih berupa bangunan semi permanen dengan kondisi dinding dan lantai memiliki bagian yang masih berupa kayu. Hal ini tentu berakibat kepada belum idealnya bangunan bagi kaum difabel. Tangga merupakan kesulitan utama yang dirasakan. Sosialisai perda pun belum dilakukan oleh pemerintah daerah ke instansi pendidikan. Madrash ini juga berada dibawah atau milik swasta. Bangunan kelas masih berupa sarana lama namun dirawat dengan baik dapat dilihat seperti gambar berikut.

Gambar B. 4 Keadaan kelas

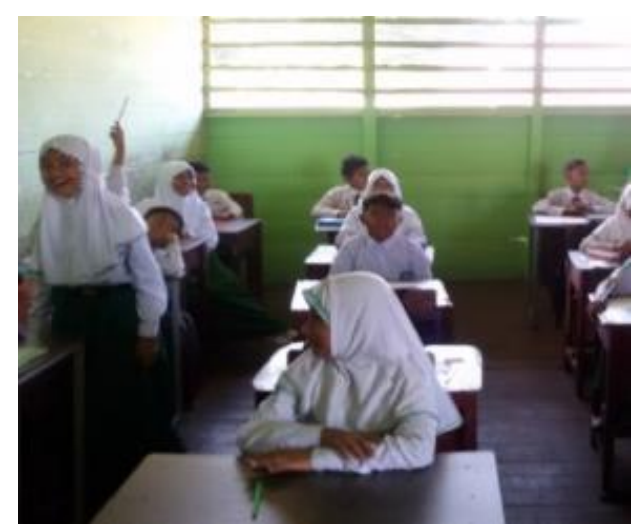




\section{MADRASAH}

Jurnal Pendidikan dan Pembelajaran Dasar

p ISSN: 1979-5599 | e ISSN: 2502-194X

Page $\mid 81$

\section{4) Taman Pemuda Islam (TPI) Elementary School Keramat}

Sekolah yang beralamat di Jalan Keramat Raya Nomor 21 RT 17 Banjarmasin memiliki bangunan yang boleh dikatakan masih belum ramah difabel atau belum layak karena bangunan di madrasah ini merupakan bangunan tua dan sebagian besar memiliki material berupa kayu atau papan. Tetapi fasilitas mendukung dapat dikatakan baik seperti kursi maupun meja yang memiliki material ringan aman bagi siswa serta tidak berbahan kayu. Ketidaksiapan sekolah mungkin dapat dimaklumi dikarenakan sosialisasi Perda belum diketahui serta karena Madrasah ini dibawah yayasan maka pembangunan sarana dan prasarana memerlukan kajian yang sangat mendalam oleh pihak yayasan. Berikut adalah dokumentasi yang dapat ditelaah terkait fasilitas di TPI Keramat;

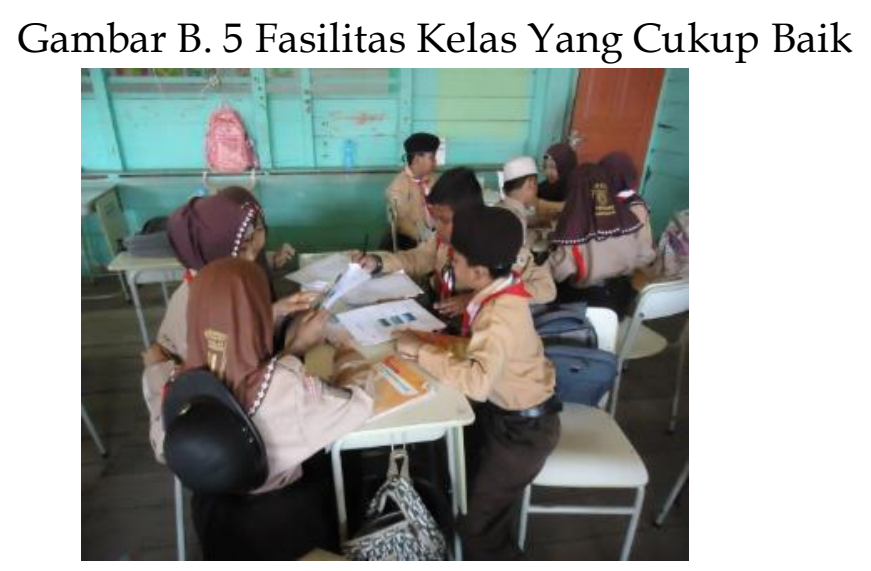

5) MIS Al Furqon Muhammadiyah

Sekolah yang beralamat di jalan Sutan Adam Komplek Kadar Permai 2, secara fisik bangunan memang sudah permanen. Hal ini tentu dikarenakan berada di bawah yayasan yang memang kuat secara finansial dan professional. Tetapi kalau berbicara ideal mengacu Permen PU No. 30/PRT/M/2006 yang merupakan acuan terkait fasilitas ataupun akses gedung dapat dikatakan susah mencapainya apabila sosialisasi aturan dan kebijakan terkait belum dilakukan. Hampir semua bangunan belum memiliki tramp untuk yang menggunakan kursi roda. Hal ini tentu harus menjadi perhatian bersama.

\section{6) MIS Istiqomah}

Sekolah yang beralamat di jalan Pekapuran Raya RT 42 Banjarmasin Selatan memiliki bangunan yang cukup baik namun seperti kebanyakan madrasah terutama dibawah kepemilikan swasta masih belum ideal. Kamar kecil masih belum mudah diakses oleh peserta didik. Ruang sekolah sebagian besar juga masih belum menerapkan aturan terkait dan hal ini tentu tidak menjadikan alasan kita untuk menyalahkan sekolah atau madrasah. Hal tersebut tentu memerlukan kerjasama berbagai pihak (pemerintah, sekolah dan masyarakat). Mendudukan "pendidikan inklusif" sebagai suatu hal yang dasar dalam layanan pendidikan tentu tidak sesederhana yang dipikirkan. Inklusi harus dipahami sebagai suatu perubahan paradigma di kalangan stakeholders yang tidak hanya dalam tataran abstrak dan teoritis (Yulianto, 2014, p. 28). Memang menuju keidealan akan sangat berat, tetapi memang peran dari berbagai pihak yang terkait harus menjadi 
komitmen bersama. Kebanyakan MIS memang bertingkat dua memiliki akses menuju kelas atau ruang pembelajaran yang berada pada tingkat dua dan masih berupa tangga sederhana atau belum sesuai dengan standar aturan aksesibilitas.

7) MIS Al Ashriyah

Sekolah yang beralamat di jalan Sulawesi No.5 Pasar Lama Kecamatan Banjarmasin Tengah Kota Banjarmasin merupakan sebuah madrasah yang meiliki bangunan cukup baik, tetapi memang sekali lagi dikatakan bahwa mencapai keidealan tentu memerlukan kerjasama berbagai pihak. Pemerintah tentu tidak dapat menjadi satusatunya yang kita tunggu untuk mewujudkannya. Tetapi perlu peran dari masyarakat maupun orang tua untuk dapat mewujudkannya. Bangunan sudah mulai perbaikan berupa bangunan yang sifatnya permanen. Namun memang tangga dan toilet perlu penyesuaian agar seusuai dengan standar ramah disabilitas.

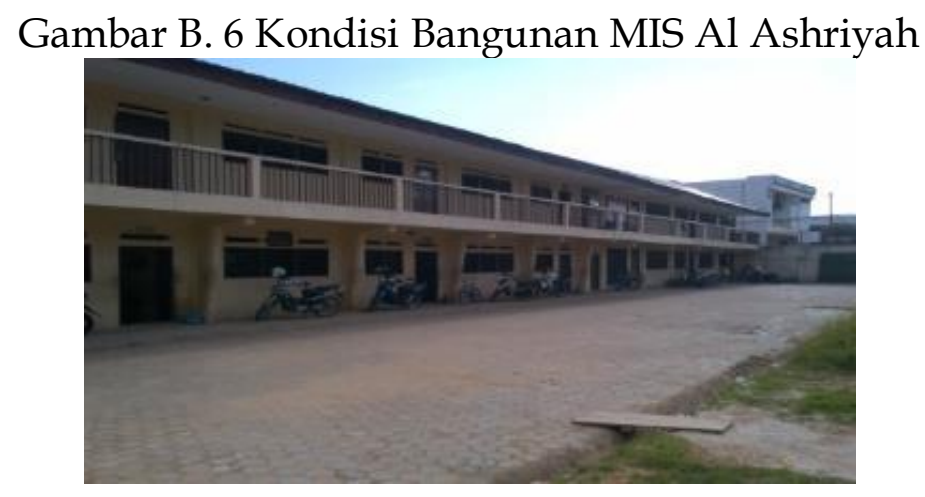

\section{Pembahasan}

Permasalahan utama berupa akses ini tentu akan menjadi teratasai apabila sekolah/madrasah dalam pembangunan sarana pendukung menggunakan atau berpedoman atau memiliki acuan berdasarkan Permen PU, sehingga terdapat standarstandar yang dapat terpenuhi bagi kemudahan atau akses bagi disabilitas. Kurangnya informasi terkait hal ini tentu harus menjadi bahan masukan bagi pemerintah dalam hal ini pemerintah daerah selaku operator pendidikan di daerah ataupun bagi kanwil Kemenag di setiap provinisi, bahwa memang masih terdapat fakta bahwa sekolah/madrasah belum banyak mengetahui aturan terkait akses tersebut. Hal ini dimaksudkan agar kita bersama mampu menciptakan fasilitas sekolah yang ramah bagi kaum disabilitas atau harapannya, instansi pendidikan dibawah kementrian agama kota Banjarmasin dapat menyediakan fasilitas penunjang yang minimal dalam akses pendidikan tersebut.

Pelaksanaan sekolah inklusif seperti di Aceh pada SDN 25 merupakan bentukan dan dikelola oleh salah satu NGO internasional yaitu Helen Keller International (HKI). Sehingga pengelolaan yang dilakukan oleh HKI yang selalu mengevaluasi dan memberikan pelatihan kepada guru (Anzari, Sarong, \& Rasyid, 2018, p. 63). Faktor penghambat seperti sosial-budaya (cultural and sosial barriers) serta factor ekonomi tentu menjadi hambatan yang cukup besar. Untuk itulah akses pendidikan menjadi salah satu cara agar para penyandang disabilitas mampu dan mau untuk berinteraksi pada tempat yang memang seharusnya. Inklusifisme pendidikan tentu manjadi salah satu yang dapat mewujudkannya. Sambutan hangat dan bersahabat dari masyarakat dalam hal ini adalah lingkungan sosial ataupun lingkungan sekolah akan menjadi sebuah energi bagi 


\section{MADRASAH}

Jurnal Pendidikan dan Pembelajaran Dasar

p ISSN: 1979-5599 | e ISSN: 2502-194X

Page $\mid 83$

arus perbaikan dan menjadi sebuah dorongan semangat bagi para penyandang untuk dapat berinteraksi secara lebih luas dan nyaman tentunya.

Pada negara-negara maju, apresiasi dan pengakuan hak-hak difabel telah berjalan dengan baik. Bahkan di Negara maju seperti AS ada pengakuan dan jaminan proteksi terkait hak kaum difabel seperti hak dalam akses pendidikan, perumahan, lapangan pekerjaan, kesehatan sampai degan sosial security. Di AS terdapat jaminan bagi difabel seperti aksesibilitas lingkungan dan bangunan, penyediaan lapangan pekerjaan dan pendidikan yang layak serta jaminan sosial bagi difabel bagi yang mengalami disabilitas yang cukup serius atau seringkali disebut "always patient" yang disebut dengan American Disability of Act (Repindowaty, Harahap, \& Bustanuddin, 2015). Terkait aspek yuridis seperti yang tercantum pada UU nomor 8 tahun 2016 disebutkan terdapat 10 hal terkait hak pendidikan untuk penyandang disabilitas yang meliputi hak; a) pendidikan yang bermutu. b) kesamaan kesempatan untuk menjadi pendidik atau tenaga kependidikan, c) kesempatan yang sama sebagai sebagai penyelenggara pendidikan dan d) akomodasi yang layak sebagai peserta didik. Namun pada kenyataanya hal itu belum ada dan belum dapat dikatakan terwujud melalui fasilitas yang belum ramah difabel atau masih belum memiliki kemudahan akses bagi difabel.

Selain itu masih pada UU yang sama pada bagian keempat belas terkait hak aksesibilitas pada pasal 18 disebutkan kaum difabel akan a) memperoleh kemudahan dalam memanfaatkan fasilitas umum atau fasilitas publik dan b) dapat memperoleh akomodasi yang layak dalam pemenuhan aksesibilitas individu. Hak individu penyandang disabilitas begitu diperhatikan dalam memperoleh aksesibilitas ini. Hal ini bersesuaian pada butir $b$ yang mengaskan bahwa penyandang disabilitas diharapkan akan mendapat kelayakan dalam akses terhadap fasilitas tersebut. Anak disabilita s harus menikmati kehidupan yang utuh dan layak dalam keadaan-keadaan yang menjamin martabat, meningkatkan kepercayaan diri, dan mempermudah partisipasi anak (Asisten Deputi Pemenuhan Hak Pendidikan Anak Deputi Tumbuh Kembang, 2014). Negara dalam hal ini pemerintah baik pusat atau daerah tentu harus memperhatikan hal ini, dikarenakan amanat UU No. 8 Tahun 2016 pada bagian ketiga tentang Pendidikan pada pasal 40 ayat 1 disebutkan bahwa Pemerintah dan Pemerintah Daerah memiliki kewajiban untuk menyelenggarakan pendidikan untuk Penyandang Disabilitas sebagaimana amanat aturan hukum di Indonesia. Pemerintah memang harus ada dan hadir dalam hal tersebut sesuai dengan wewenang yang dimilikinya.

Pendidikan inklusi merupakan alternatif bagi anak penyandang disabilitas. Dengan pelaksanaan pendidikan inklusif di Indonesia, anak penyandang disabilitas memiliki pilihan untuk bersekolah di sekolah inklusi atau disekolah luar biasa. Dewasa ini para pemerhati pendidikan serta praktisi pendidikan sedang menggaungkan semangat inklusif dalam dunia pendidikan, namun kebutuhan khusus bagi peserta didik berkebutuhan khusus harus tetap diperhatikan. Hal ini dikarenakan tidak semua anak berkebutuhan khusus mampu menjadi peserta didik di sekolah inklusi (Rizky, 2014, p. 54). Mengapa penyandang disabilitas harus diikutsertakan dalam pendidikan formal di Indonesia. Hal tersebut dikarenakan adanya kewajiban untuk mengikutsertakan anak penyandang disabilitas dalam program wajib belajar 12 tahun. Kemudian sekolah juga wajib mengutamakan anak penyandang disabilitas disekitar sekolah. Hal ini juga berdasarkan aturan yang dikeluarkan oleh Kementrian Sosial yang telah mengeluarkan 
Peraturan Menteri Sosial RI Nomor 21 Tahun 2017 tentang penerbitan kartu penyandang disabilitas (KPD) yang bertujuan untuk memperoleh akses layanan dalam penghormatan, pemajuan, perlindungan dan pemenuhan hak penyandang disabilitas.

Oleh sebab itu inklusi bukan sekedar memasukkan anak penyandang cacat ke dalam sistem yang kaku seperti yang ada sekarang, dan bukan persoalan membiasakan atau membiarkan proses adaptasi anak kepada sistem yang berlaku (Alimin, 2013, p. 173). Kesetaraan menjadi poin penting dalam penyelenggaraan pendidikan. Kota Banjarmasin sebagai ibukota Provinsi Kalimantan Selatan telah mengeluarkan Perda nomor 17 Tahun 2013 terkait hal tersebut. Perda tersebut pada pasal 9 butir 1 menyebutkan bahwa penyelenggara pendidikan pada semua jalur, jenis dan jenjang pendidikan selayaknya dan harus memberi kesempatan serta perlakuan yang setara dan wajib menerima peserta didik Penyandang Disabilitas. Selanjutnya sekolah wajib memberikan pelayanan yang disesuaikan dengan kondisi dan potensi peserta didik penyandang disabilitas dengan tetap memperhatikan kualitas. Berdasarkan perda tersebut kita dapat memaknai bahwa sekolah regular dapat dan seharusnya memberi kesempatan bagi peserta didik difabel untuk bersekolah di sekolah umum atau regular. Penerimaan peserta didik berkebutuhan khusus di sekolah regular pada pasal 14 ayat (2) dinyatakan pada butir a yang menyebutkan bahwa peningkatan aksesibilitas layanan pendidikan yang merata, bermutu dan proporsional juga akan di nikmati oleh segenap lapisan masyarakat. Namun tetap memperhatikan peningkatan kualitas sarana dan prasarana pendidikan yang tetap bermutu, kondusif serta efektif yang dinyatakan pada butir b.

Kurangnya guru pembimbing khusus (GPK) sering menjadi penyebab utama berjalan tidaknya sekolah inklusif (Sulthon, 2019). Sosialisasi terkait kebijakan pendidikan setara bagi penyandang disabilitas tentu harus di fokuskan sebelum program ini dilaksanakan. MIS yang pembiayaan sekolah sebagian besar melalui iuran atau spp yang dibayar oleh siswanya tentu memerlukan dana yang tidak kecil untuk membuat sekolah/madrasah menjadi ramah bagi difabel. Berdasarkan UU No. 8 Tahun 2016 disebutkan bahwa Pemda harus menginisiasi serta membentuk Unit Layanan Disabilitas (ULD) untuk mendukung penyelenggaraan pendidikan inklusif yang dilaksanakan pada tingkat dasar. ULD berdasarkan UU tersebut mempunyai fungsi dalam peningkatan kompetensi pendidik atau guru serta tenaga kependidikan di sekolah regular dalam menangani peserta didik penyandang disabilitas. Kebijakan ini tentu harus menjadi prioritas, karena pendidikan merupakan salah satu jalur sosialisasi yang paling efektif dalam mengenalkan program pemerintah dengan baik. Akses bagi penyandang disabilitas dimaksudkan agar tidak ada penggolongan atau diferensiasi sosial terkait penyandang disabilitas. Seperti kita ketahui bersama pendidikan merupakan salah satu saluran dalam proses sosial masyarakat untuk naik ataupun turun melalui mobilitas sosial vertikal naik atau turun.

Terkait isu aksesibilitas bagi anak berkebutuhan khusus, Indonesia telah memiliki regulasi nasional, seperti Permen PU No 30 Tahun 2006. Hal ini sebagai acuan dasar aksesibiltas yang terdapat pada bangunan atau gedung serta lingkungan. Tetapi berdasarkan penelitian terhadap 125 bangunan public di Kota Malang. Sebagian besar disebutkan tidak ramah bagi penyandang disabilitas (Syafi"ie, 2014, p. 273). Sosialiasi terkait fasilitas tentu harus sesuai dengan Permen PU No 30 Tahun 2006 tentang Pedoman Teknis Fasilitas dan Aksesibilitas Pada Bangunan Gedung dan Lingkungan harus benar-benar dilaksanakan. Kemudian akan muncul pertanyaan apakah sekolah 


\section{MADRASAH}

Jurnal Pendidikan dan Pembelajaran Dasar

p ISSN: 1979-5599 | e ISSN: 2502-194X

regular juga harus menerima peserta didik berkebutuhan khusus, apakah peserta didik berkebutuhan khusus hanya akan boleh mengenyam pendidikan di SLB. Maka kita harus mencermati UU nomor 8 tahun 2016 tentang diasabilitas yang mentebutkan bahwa pada pasal 32 ayat (1) disebutkan bahwa pendidikan khusus bagi peserta didik dapat pula diselenggarakan pada semua jalur dan jenis pendidikan pada jenjang pendidikan dasar dan menengah. Namun pada ayat (3) Anak berkebutuhan khusus dapat mengikuti pendidikan pada satuan pendidikan umum dan/atau satuan pendidikan kejuruan sebagaimana dimaksud pada ayat (2) dalam bentuk Pendidikan Inklusif.

Pelaksanaan pendidikan inklusif memang masih terdapat pro dan kontra atau masih menjadi kontroversi. Tetapi proses inklusi tentu memiliki berbagai manfaat yang tidak sedikit. Proses layanan inklusi disesuaikan dengan kebutuhan individu yang berbeda dalam konteks pembersamaan yang klasikal (Jauhari, 2017, p. 33). Dengan demikian dapat dipahami bahwa pendidikan inklusif memang sangat ideal dalam memberikan layanan pendidikan bagi siswa difabel, karena mengandung banyak manfaat. Pertama, tercapainya pemerataan pendidikan bagi mereka yang selama ini tak tercapai dengan adanya sekolah khusus (SLB dan SDLB). Kedua, pendidikan inklusif dapat menghilangkan sekat diskriminasi. Ketiga, belajar berinteraksi dalam lingkungan masyarakat secara normal. Keempat, sekolah inklusif memiliki nilai terapi sosial psikologis, serta akan meningkat rasa percaya dirinya dan keterikatan sosialnya. sekolah inklusif memiliki pengaruh yang besar terhadap perkembangan psikologis siswa difabel, yaitu memupuk rasa aman, menilai dirinya positif (self concept), harga diri (self esteem), serta kepercayaan diri anak (self confident)yang tentu dimiliki setiap anak (Pratiwi, 2016, p. 263). Dibutuhkan sinergi yang kuat dari stakeholder utamanya di bidang pendidikan dalam rangka memperkuat sosialisasi, pengawasan, edukasi dan lain sebagainya (Armansyah, 2015, p. 36). Mewujudkan sekolah yang inklusif serta ramah bagi difabel tentu menjadi keinginan bersama, namun proses kearah sana harus dilalui dengan mempersiapkan sarana pendukung serta sosialiasi peraturan yang memadai, sehingga program ini akan dapat berjalan dengan baik.

\section{KESIMPULAN}

Pendidikan setara yang dicita-citakan tentu menjadi tanggung jawab berbagai pihak seperti Pemerintah, masyarakat dan unsur lainnya. Dasar hukum yang ada telah mencoba untuk menjadi sebuah dasar pada gerakan kesetaraan ini. Negara telah mengakomodir HAM pada berbagai bidang, yang salah satunya adalah bidang pendidikan melalui UUD, UU hingga Perda yang seharusnya dapat menjadi dasar pelaksanaan praktik kesetaraan dalam berbagai bidang khusunya dalam bidang pendidikan yang menjadi fokus penelitian ini.

Mewujudkan sekolah inklusi atau mewujudkan jenjang pendidikan yang setara tentu menjadi hal yang dicita-citakan berbagai pihak. Berdasarkan observasi yang dilakukan pada tujuh MIS di Kota Banjarmasin dapat dikatakan belum layak atau ramah difabel, seperti yang diamanatkan melalui produk hukum yang dihasilkan. Berdasarkan temuan dari observasi yang dilakukan pada 7 (tujuh) MIS di Kota Banjarmasin maka dapat kami simpulkan bahwa masih belum meratanya sosialisasi terkait perda nomor 17 Tahun 2013 tentang perlindungan dan pemenuhan hak kaum disabilitas, sehingga produk hukum setelahnya seperti UU no 8 tentang Disabilitas pun banyak tidak 
diketahui oleh lembaga pendidikan yang diobservasi. Kami menyadari bahwa ada investasi yang amat besar terkait dana dalam mempersiapkan fasilitas pendukung agar sekolah atau madrasah dapat dikatakan layak bagi difabel. Hal ini tentu menjadi perhatian bersama bagi pemerintah dan swasta agar cita-cita akses pendidikan yang mudah dapat diwujudkan.

Undang-undang nomor 8 tahun 2016 terkait disabilitas menjadi sebuah wujud keseriusan pemerintah dalam mengupayakan kesetaraan pendidikan bagi seluruh lapisan masyarakat dan warga negara. Tetapi memang kesiapan sarana dan prasarana tentu menjadi hal yang masih belum dapat dipenuhi untuk mendukung keberhasilan tersebut. Masih banyak lembaga pendidikan dasar di bawah Kementrian Agama seperti MIS yang sedang diobservasi belum memudahkan akses bagi peserta didik. Fasilitas yang ada seperti ruang kelas, selasar kelas, tangga serta toilet masih harus dibenahi dan disesuaikan dengan Permen PU No. 30/PRT/M/2006 yang mengatur fasilitas, akses dan penunjang lainnya pada gedung pemrintah ataupun umum. Hal ini memang tidak akan mudah tetapi juga bukan hal yang mustahil dikerjakan. Sinergi yang antara berbagai pihak atau dengan kerjasama berbagai pihak yang ada, maka perwujudan sekolah/madrasah inklusi tersebut akan mampu diwujudkan.

\section{REFERENSI}

Alimin, Z. (2013). Paradigma Pendidikan Inklusif Sebagai Upaya Memperluas Akses dan Perbaikan Mutu Pendidikan. JASSI Anakku, 12.

Alsafran, A. Y., \& Amireh, M. Y. (2019). The Difference between Performance Levels on the Adaptive Behavior Scale for Students with Mild Intellectual Disabilities Who are included in Public Schools Compared to Those Enrolled in Special Education Centers in Amman. Journal of Education and Practice, 10(30).

Anzari, M., Sarong, A. H., \& Rasyid, M. N. (2018). Hak Memperoleh Pendidikan Inklusif Terhadap Penyandang Disabilitas. Syiah Kuala Law Jurnal, 2 No. 1, 57-73.

Armansyah, Y. (2015). "Sekolah Ramah Anak" Berbasis Perda : Studi Pada Peraturan Walikota Jambi Nomor 189 Tahun 2010 Tentang Kawasan Tanpa Asap Rokok (KTAR). Harkat, 11(1), 31-40.

Asisten Deputi Pemenuhan Hak Pendidikan Anak Deputi Tumbuh Kembang. (2014). Kebijakan Pengembangan Sekolah Ramah Anak. Jakarta.

Escribano, R., Treviño, E., Nussbaum, M., Torres, D., \& Carrasco, I. D. (2019). How much does the quality of teaching varyat under-performing schools? Evidence from classroom observations in Chile. International Journal of Educational Development, 72, $1-13$.

Hasanah, D. U. (2016). Kekerasan Dan Diskriminasi Terhadap Perempuan Dalam Pandangan Hukum. Harkat, 12(2), 109-116.

Irwanto, I., Fransiska, A., \& Lusli, M. (2016). Analisis Situasi Penyandang Disabilitas Di Indonesia : Sebuah Desk-Review. (May), 1-37.

Kementrian Hukum dan HAM. Undang-Undang Nomor 8 Tahun 2016 Tentang Penyandang Disabilitas. , (2016).

Kementrian Pendidikan Nasional. Undang-Undang No 20 Tahun 2003 Tentang Sistem Pendidikan Nasional. , (2003).

Kementrian Pendidikan Nasional. Peraturan Menteri Pendidikan Nasional Nomor 70 Tahun 2009 Tentang Pendidikan Inklusif Bagi Peserta Didik Yang Memiliki Kelainan dan 


\section{MADRASAH}

Jurnal Pendidikan dan Pembelajaran Dasar

p ISSN: 1979-5599 | e ISSN: 2502-194X

Pa g e 187

Memiliki Potensi Kecerdasan Dan/Atau Bakat Istimewa. , (2009).

Mahabbati, A. (2014). Kebijakan, Implementasi dan Isu Strategis Pendidikan Bagi Individu Berkebutuhan Khusus. Jurnal Pendidikan Islam, 3(1), 31. https://doi.org/10.14421/jpi.2014.31.31-46

Pratiwi, J. C. (2016). (2016). Sekolah Inklusi Untuk Anak Berkebutuhan Khusus: Tanggapan Terhadap Tantangan Kedepannya. Prosiding Ilmu Pendidikan. Retrieved from http://www.jurnal.fkip.uns.ac.id/index.php/pip/article/view/7725

Repindowaty, R., Harahap, \& Bustanuddin. (2015). Perlindungan Hukum Terhadap Penyandang Disabilitas Menurut Convention on the Rights of Persons With Disabilities (Crpd). Jurnal Inovatif, VIII(1), 17-29.

Rizky, U. F. (2014). Identifikasi Kebutuhan Siswa Penyandang Disabilitas Pasca Sekolah Menengah Atas. Indonesian Journal of Disability Studies, 1 Issue 1, 52-59.

Salmah, S. (2018). Aksesibilitas Pendidikan Bagi Kaum Disabilitas Pada Madrasah Ibtidaiyah Negeri (MIN) di Kota Banjarmasin (Rahmad, ed.). Yogyakarta: K -Media.

Subur, Qosim, M. N., \& Nugroho, I. (2018). Implementasi Sekolah Ramah Anak Dalam Membentuk Budaya Sekolah Di SDN Geger Tegalrejo. Prosiding Konferensi Nasional Ke-7 APPPTMA, (March), 3-8.

Sulthon. (2019). PENDIDIKAN DASAR INKLUSIF DI KABUPATEN PATI: Harapan dan Kenyataan. INKLUSI: Journal of Disability Studies, 6, No. 1, 151-172.

Undang-Undang Dasar 1945. , (2002).

Yusraini. (2013). Kebijakan Pemerintah Terhadap Pendidikan Inklusif. Media Akademika, Vol. 28 No. 